\title{
Laboratory Scaled Coal Dust Explosions and Physical Test Results for CFD Explosion Models
}

\author{
Patrick Maier', Philipp Hartlieb', and Jürgen F. Brune² \\ ${ }^{1}$ Chair of Mining Engineering and Mineral Economics, Montanuniversität Leoben, Leoben, Austria \\ ${ }^{2}$ Mining Engineering Department, Colorado School of Mines, Golden, USA
}

Received March 30, 2020; accepted April 4, 2020; published online April 22, 2020

\begin{abstract}
The work was carried out during an exchange program of several-months at the Colorado School of Mines (CSM) in Golden, Colorado. The goal of the thesis was to investigate scaled methane and coal dust explosions for the validation of CFD models. A series of different tests were performed in a horizontal, cylindrical steel reactor with a length of $1.5 \mathrm{~m}$ and a diameter of $63 \mathrm{~mm}$ at a scale of about 1:30. These tests are used to investigate the effect of coal dust on the combustion process by measuring the velocity of propagation. Furthermore, a reactor was constructed to visualize coal dust explosions, their interaction with the methane flame and the entrainment of coal dust particles. These approaches will help to understand the relationship between the particle dispersion and the turbulent flame propagation and to prepare experiments in a larger, $\sim 1: 5$ scaled steel reactor $(L=31 \mathrm{~m}, \mathrm{D}=0.71 \mathrm{~m})$.
\end{abstract}

Keywords: Coal dust explosion, Methane-air mixture, Coal dust experiments, Flame propagation velocity

Kohlenstaubexplosionen im Labormaßstab und physikalische Ergebnisse für CFD-Modelle

Zusammenfassung: Die Arbeit wurde im Zuge eines mehrmonatigen Auslandaufenthaltes an der Colorado School of Mines (CSM) in Golden, Colorado durchgeführt. Das Ziel der Thesis war es, skalierte Methan- und Kohlenstaubexplosionen zur Validierung von CFD-Modellen zu untersuchen. Es wurde eine Reihe von Tests in einem horizontalen, zylindrischen Stahlreaktor mit einer Länge von $1,5 \mathrm{~m}$ und $63 \mathrm{~mm}$ Durchmesser im Maßstab von ca. 1:30 durchgeführt, um den Effekt von Kohlenstaub auf den Verbrennungsprozess zu untersuchen, indem die Ausbreitungsgeschwindigkeit gemessen wurde. Des Weiteren wurde ein Reaktor zur Vi-

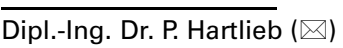

Chair of Mining Engineering and Mineral Economics,

Montanuniversität Leoben,

Franz Josef Str. 18,

8700 Leoben, Austria

Philipp.hartlieb@unileoben.ac.at sualisierung von Kohlenstaubexplosionen konstruiert, um die Wechselwirkung mit der Methanflamme sowie die Mitnahme von Kohlenstaubpartikeln zu studieren. Diese Ansätze werden dazu beitragen, die Beziehung der Partikeldispersion mit der turbulenten Flammenausbreitung zu verstehen und Versuche in einem größeren, 1:5 skalierten Stahlreaktor $(L=31 \mathrm{~m}, \mathrm{D}=0,71 \mathrm{~m})$ vorzubereiten.

Schlüsselwörter: Kohlenstaubexplosion, Methan-LuftGemisch, Kohlenstaubversuche, Flammenausbreitung

\section{Introduction}

In underground coal mines, coal dust and methane are produced by the mining processes of coal seams. Coal dust particles deposit on the entries, including the roof, rib, and floor areas, and can cause an explosion if they are entrained and ignited. In underground coal mines, fine coal particles that are produced by cutting processes can induce an explosion when entrained and ignited, for example, initiated from a methane explosion [1]. Such processes caused several disasters of mine fires like the explosion at the Upper Big Branches with 29 fatalities in 2010, and the Jim Walter No. 5 mine which killed 13 miners. The high number of fatalities in underground coal mines in the United States illustrates that coal dust explosions can occur if measurements for prevention are inadequate. Since NIOSH closed the Lake Lynn Laboratory for full-scale physical testing, there is no longer a facility available for suitable coal dust explosion tests in the U.S. However, scaled laboratory and field tests in combination with numerical models can reliably reproduce results of full-scale mine tests to investigate the behavior of coal dust in relation to methane gas explosions. 


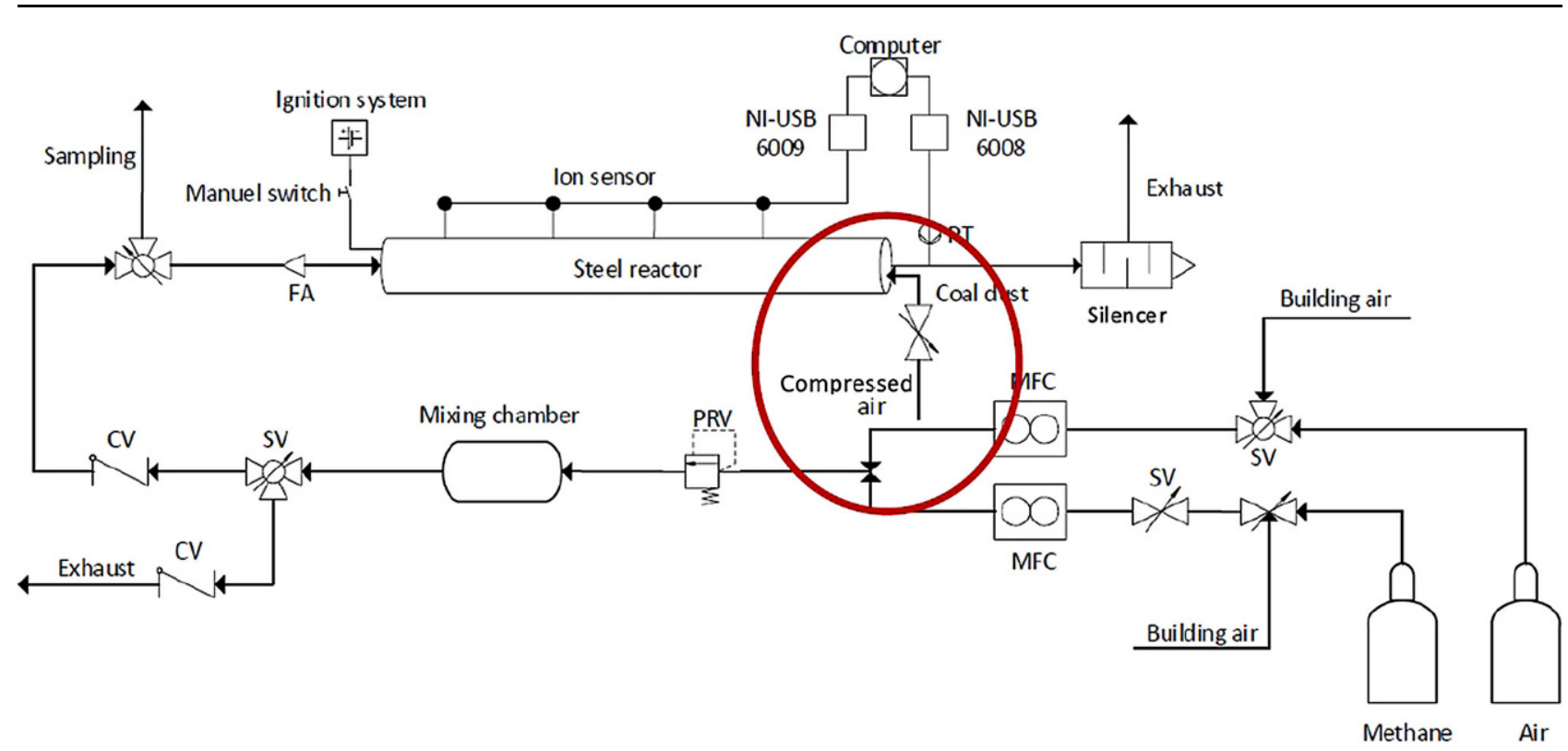

Fig. 1: Schematic layout of the experimental setup in thelaboratory at CSM. PTpressuretransducer, CV checkvalve, FAflame arrestor, SVsolenoid valve. The red circle marks the injection system for tests with pre-dispersed coal dust

\section{Materials and Methods}

\subsection{Experimental Setup}

For the procedure of the experiments, a laboratory-scale horizontal steel tube is used to investigate the flame propagation of ignition of a methane-air concentration in presence of coal dust. The setup provides multiple data points for future comparison of CFD simulation tests and to extrapolate them to larger combustion geometries. The experiments were performed under standard conditions at about $294 \mathrm{~K}$ and $83 \mathrm{kPa}$, the atmospheric pressure in Golden, CO.

Fig. 1 shows a schematic of the experimental setup consisting of a zero-grade air and compressed methane cylinders, mass flow controllers (MFC), a mass flow meter (MFM), a mixing tank, a data acquisition (DAQ) device, and a steel tube with four ports for the ion sensors on the longitudinal axis. Several safety features have been installed to enable a secure operation of the system.

The laboratory-scaled reactor has a length/diameter (L/D) ratio of 26 with an open end to the atmosphere. The inlet and ignition system of the premixed combustible methane-air mixture is at the closed end. The threaded sensor ports are equally apart with a distance of $38 \mathrm{~cm}$. Custom-built flame detectors are made from spark plugs that are modified to ion sensors. Each sensor is connected to its own voltage source and a common DAQ, which records the created voltage when the flame passes near the gap between the electrodes of the sensor. By the known distance between the ion sensors and the time of the detected signal, the flame propagation velocity is determined.

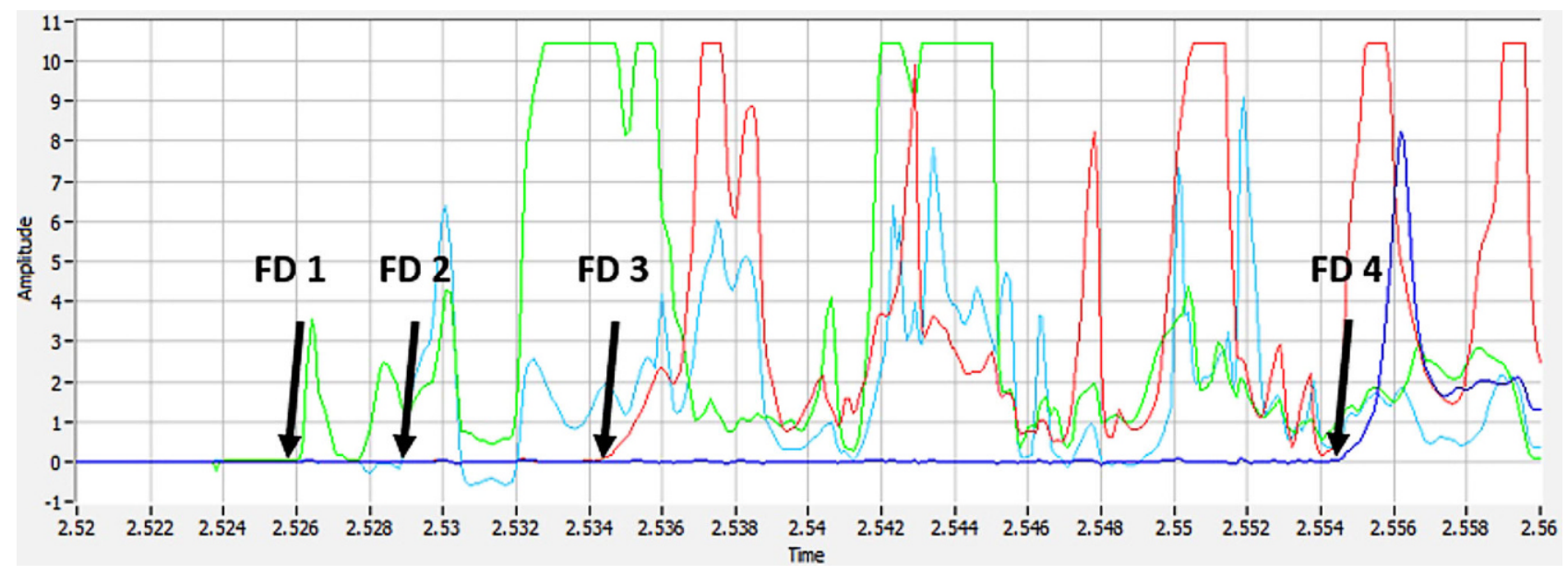

Fig. 2: Typical signal from passing of the flame. In this case the flame is produced by a torch. Each color represents an ion sensor. The first rise of the signal is where the flame is being detected the first time (FD). The diagram is a function of voltage on the $y$-axis and time on the $x$-axis 


\begin{tabular}{|ll|}
\hline $\begin{array}{l}\text { TABLE } 1 \\
\text { Specification of the Pittsburgh coal dust }\end{array}$ \\
\hline Origin of the coal & $\begin{array}{l}\text { Pittsburgh high-volatile bituminous } \\
\text { coal }\end{array}$ \\
\hline Moisture [\%] & 1 \\
\hline Volatile matter [\%] & 37 \\
\hline Fixed carbon [\%] & 56 \\
\hline Ash [\%] & 6 \\
\hline $\begin{array}{l}\text { Heating value } \\
{[\mathrm{kJ} / \mathrm{kg}]}\end{array}$ & 32,322 \\
\hline
\end{tabular}

Fig. 2 shows the example of a signal from the passing of the flame. Pittsburgh coal which is known as high volatile bituminous coal with a particle size of $\mathrm{d}_{85}<75 \mu \mathrm{m}$, represents "float" coal dust in the intakes and returns of underground coal mines.

The proximate composition of the coal is shown in Table 1. The values have been measured according to ASTM D3172 and D 1989 [2]. As ignition system, a commercial $12 \mathrm{~V}$ auto battery, a capacitor, an ignition coil and a manual switch are used. The released energy of the produced spark is approximately $60 \pm 5 \mathrm{~mJ}[3,4]$. Due to the high current of the battery, features for safe handling have been installed.

\subsection{Test Procedure}

Prior to any tests, compressed building air flows through all lines to test for potential leaks. After the safety checks, the methane flows with a rate of $1.68 \mathrm{~Pa}^{*} \mathrm{~m}^{3} / \mathrm{s}$ and the air with $18.93 \mathrm{~Pa}^{*} \mathrm{~m}^{3} / \mathrm{s}$ at a pressure of $206 \mathrm{kPa}$ through the mixing vessel to ensure a stoichiometric methane-air mixture $\left(\mathrm{CH}_{4}\right.$ concentration of $\left.9.5 \%\right)$. The flow is controlled by an MFC for the methane gas and an MFM for the zero-graded air. The combustible mixture is filled for a time of $2 \mathrm{~min} \pm 5 \mathrm{~s}$ into the steel reactor. A perforated aluminium foil covers the open end, which allows the purge of the ambient air in the reactor. To ensure stable conditions, a settling time of the gases is set to $1 \mathrm{~min} \pm 3 \mathrm{~s}$. The mixture is then ignited from the closed end of the reactor by the capacitive spark ignition system. After each test, the reactor and all lines are flushed with compressed building air, and the exhausts are sucked out by the building ventilation. Tests are perfomed with rock from Germany which ensures that the exhaust system can capture all dust particles. These experiments are used to study the influence of incombustible dust on the flame velocity and how it deviates from the experiments with the coal dust.

Two sets of experiments are conducted with either predispersed or deposited coal dust. Tests of the deposited coal dust are placed on a metal plate within a specific zone. This zone is $23 \mathrm{~cm}$ long and represents the procedure of the large-scale experiments which were performed by researchers in Kloppersbos, South Africa [5]. In addition, four different coal dust concentrations are used: $100 \mathrm{~g} / \mathrm{m}^{3}(0.5 \mathrm{~g}), 200 \mathrm{~g} / \mathrm{m}^{3}(1 \mathrm{~g}), 416 \mathrm{~g} / \mathrm{m}^{3}(2 \mathrm{~g})$, and $832 \mathrm{~g} / \mathrm{m}^{3}$ $(4 \mathrm{~g})$. As a reference, the influence on flame propagation velocity of methane-air mixture itself with and without the metal plate in the steel reactor is also analysed.

\section{Results}

\subsection{Results of the Deposited Coal Dust}

The impact of the deposited coal dust shows a reduction in the flame front propagation velocity. Fig. 3 displays the comparison of the experiments with the methane-air mixture with (obstructed) and without (unobstructed) the metal plate and the deposited coal dust with the concentrations of 100,420 , and $830 \mathrm{~g} / \mathrm{m}^{3}$. The highest velocity of $70 \mathrm{~m} / \mathrm{s}$ is measured without coal dust and occurs between the $3 \mathrm{rd}$ and 4th sensor. In contrast, the lowest velocity is $35 \mathrm{~m} / \mathrm{s}$ which occurs with a coal dust concentration of $830 \mathrm{~g} / \mathrm{m}^{3}$.
Fig. 3: Average flame front propagation velocity of all tests carried out with no dust, deposited coal dust; Operating conditions: $294 \pm 1 \mathrm{~K}$, $83 \pm 1 \mathrm{kPa}$, and $\mathrm{E}_{\text {ign }}=60 \pm 5 \mathrm{~mJ}$

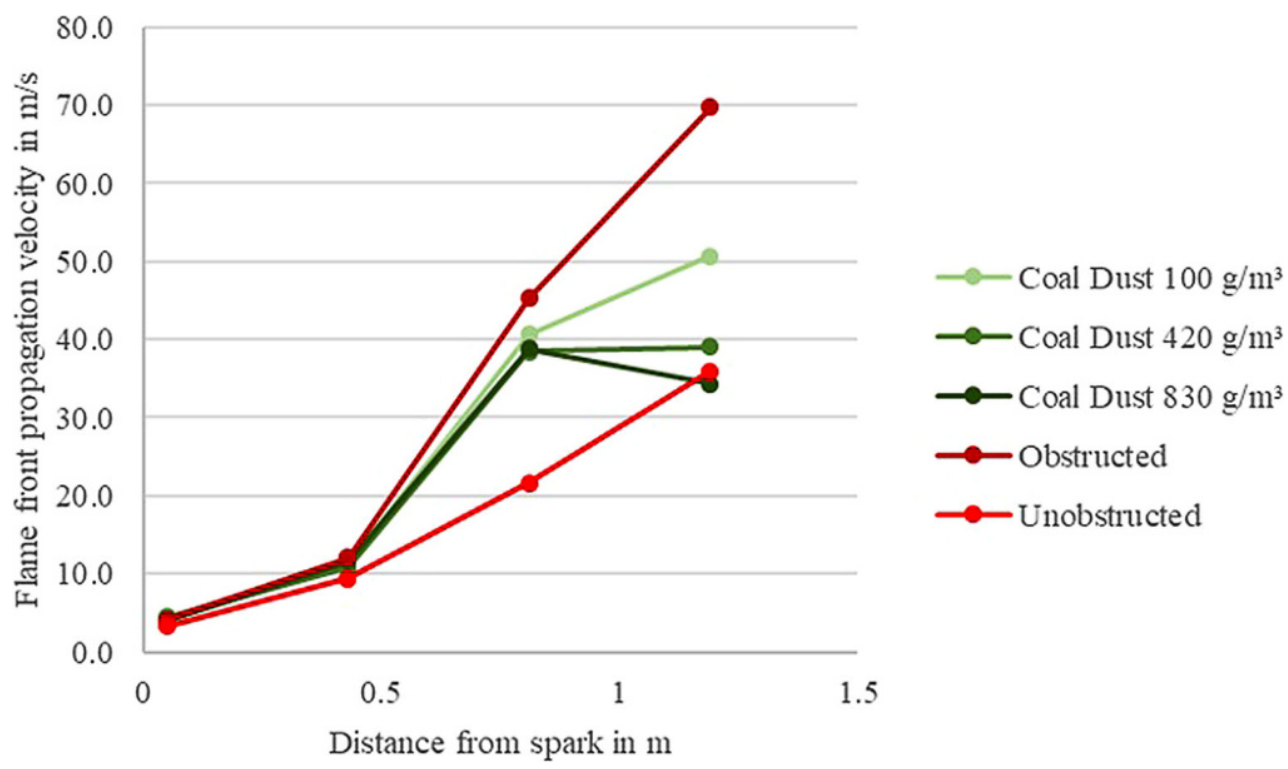


Fig. 4: Comparison of the mean flame front propagation velocity of deposited/pre-dispersed coal dust with the metal plate in the steel reactor; Operating conditions: $294 \pm 1 \mathrm{~K}, 83 \pm 1 \mathrm{kPa}$, and $E_{i g n}=60 \pm 5 \mathrm{~mJ}$

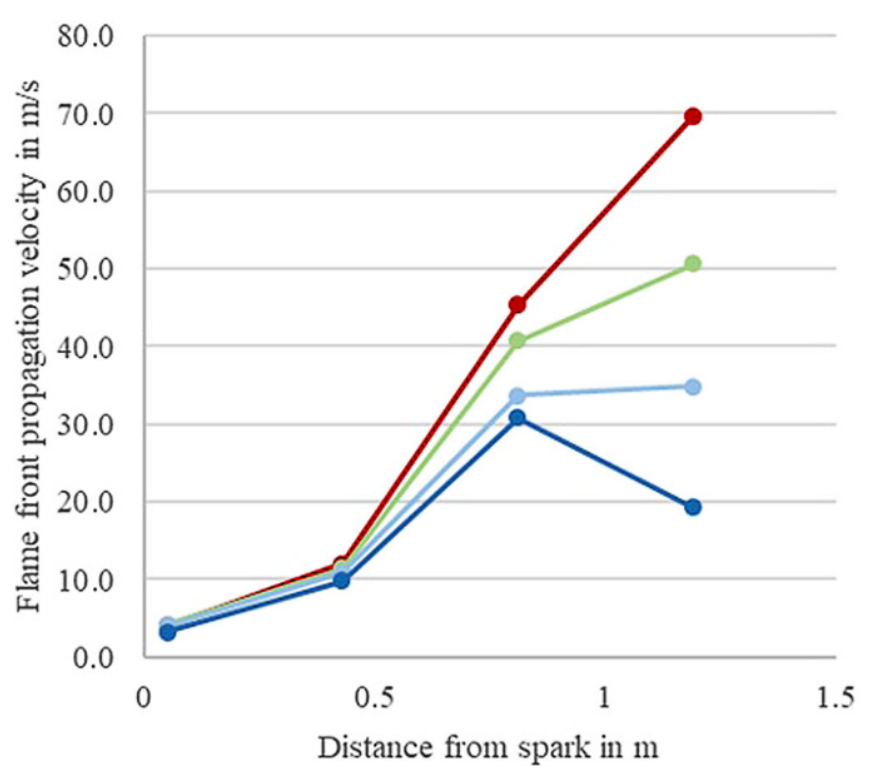

$\longrightarrow$ Obstructed

$\longrightarrow$ Coal Dust $100 \mathrm{~g} / \mathrm{m}^{3}$ deposited

$\longrightarrow$ Coal Dust $100 \mathrm{~g} / \mathrm{m}^{3}$ dispersed

$\longrightarrow$ Coal Dust $200 \mathrm{~g} / \mathrm{m}^{3}$ dispersed
Coal dust particles, which are dispersed from the shockwave of the explosion, absorb heat and energy. This absorbed energy, which is needed to develop gas substances from the volatile matter of coal dust particles, is too low to start the gas forming processes. Therefore, the amount of gas is insufficient and cannot serve as fuel for the explosion and may explain the decrease of the flame velocity.

This effect differs from the literature and the conclusions of researchers who have conducted tests in horizontal tube reactors. However, the L/D ratio and the initial ignition energy is higher. It must also be highlighted that the coal dust has been initially injected and premixed with the methaneair mixture before the ignition of the combustible solid and gas phases [6-8].

\subsection{Results of the Pre-dispersed Coal Dust}

Fig. 4 shows the results of the test when the coal dust was injected prior to the ignition of the premix. The injected coal dust has a negative effect on the flame velocity. The higher the concentration, the higher the reduction of the flame speed. This phenomenon occurs because coal dust particles provide a greater proportion of energy absorption. The diagram also displays that the mean flame velocity of the deposited coal dust occurs at a concentration of $100 \mathrm{~g} / \mathrm{m}^{3}$. It can be observed that the impact of the deposited coal dust on the flame velocity is less effective because fewer particles are dispersed, which act as an energy absorption medium. This effect is even more intensified with a higher concentration $\left(200 \mathrm{~g} / \mathrm{m}^{3}\right)$ since the average velocity in the last measuring sector is only $19 \mathrm{~m} / \mathrm{s}$.

Fig. 5 shows a series of images taken by a high-speed camera. The amount of coal dust used in this experiment is $0.5 \mathrm{~g}$ of pre-dispersed coal dust. It shows a large flame at the end of the reactor and strong blackbody radiation, which can be explained by the the high percentage of the finest coal dust particles involved and the exposure to the flame.
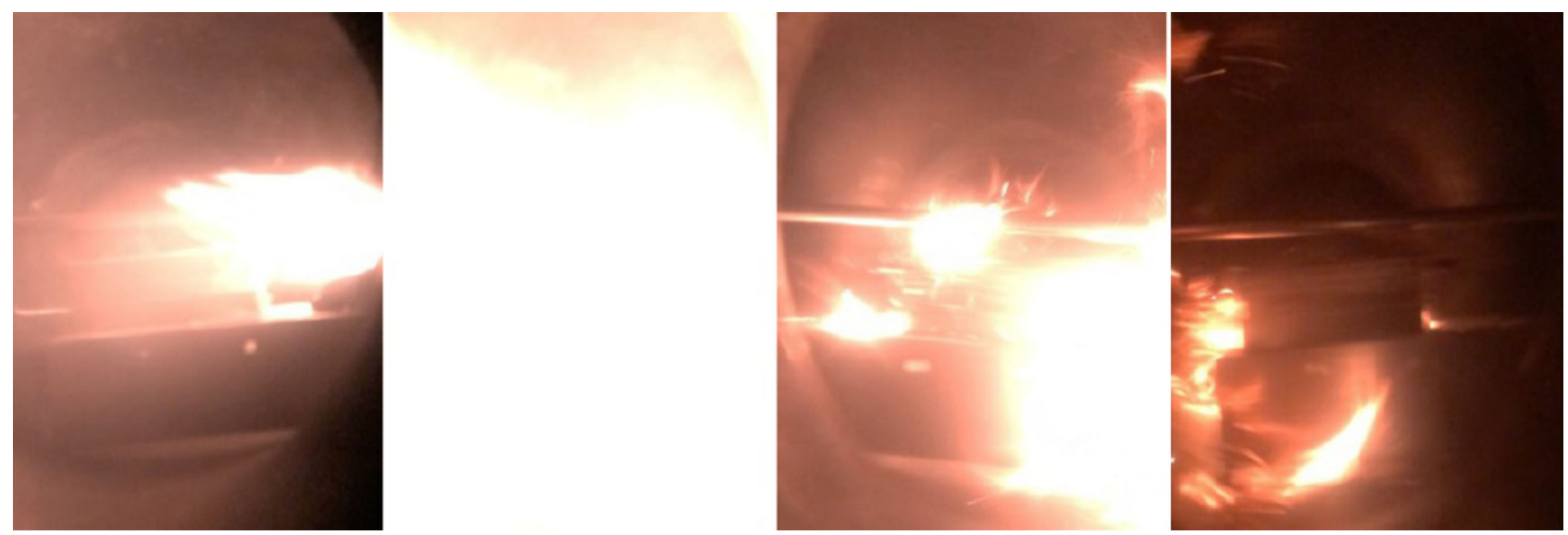

Fig. 5: Images of the experiment with $100 \mathrm{~g} / \mathrm{m}^{3}$ of pre-dispersed coal dust. The Flame was filmed from the side of the open end of the steel reactor 


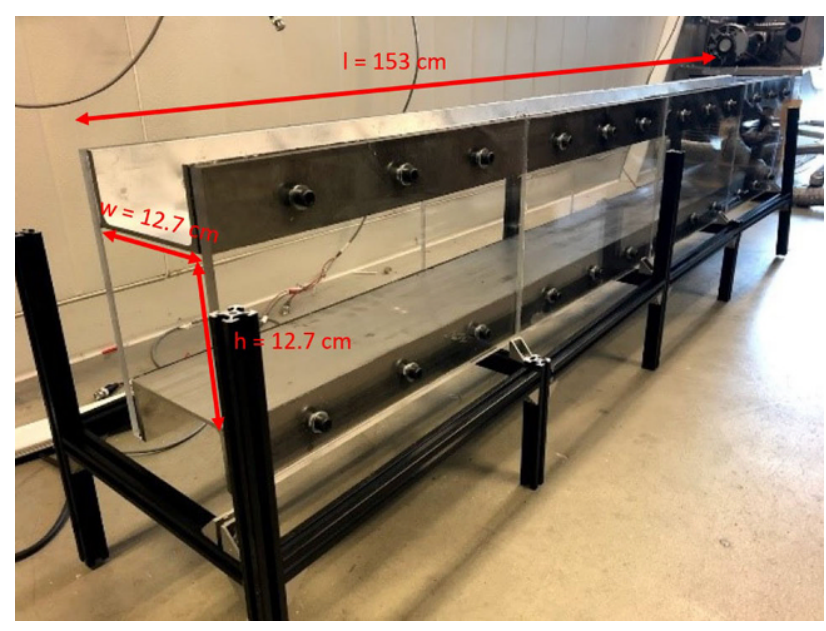

Fig. 6: Experimental reactor design, length $=153 \mathrm{~cm}$, cross $-\mathrm{sec}-$ tion $=161 \mathrm{~cm}^{2}$

\section{Design of an Experimental Reactor with Rectangular Cross-section}

The second objective of the master thesis was the design and construction of a reactor with a rectangular cross-section to resemble an underground coal mine drift. An additional requirement of the reactor is to plan transparent sidewalls for an investigation of the entrainment and dispersibility of the coal dust explosion on a laboratory scale. Fig. 6 shows the final design of the experimental reactor consisting of plexiglass with a thickness of $12.7 \mathrm{~mm}$ as sidewalls and two U-channels for stabilization. The length of the reactor is $153 \mathrm{~cm}$ and the cross-section is $161 \mathrm{~cm}^{2}$. The plexiglass is sealed and bolted to the metal channel with a graphite gasket. Additional silicon is used to seal it completely. At the one end, the reactor is covered with a layer of plexiglass with an opening to slide in the steel tube. The other end is open for the exhaust ventilation. For safety reasons, the combustible mixture will only be ignited in the steel reactor. The design ensures a comprehensive observation of the evolution of the coal dust propagation over the whole length of the reactor. High-speed imaging provides an insight into the entrainment and burning coal particles as the methane flame passes through the containing coal dust zone.

\section{Conclusions}

The highest flame propagation velocity is achieved with a horizontal metal plate in the reactor. The mean flame speed decreases with the amount of coal dust added. This effect is observed both with deposited and with pre-dispersed coal dust. It is concluded that the pulverized coal in the reactor causes radiative absorption of the energy because the residence time in the steel reactor is too short.
The coarser coal dust particles cool the flame temperature, as the initial energy of the explosion is too low to cook off volatile carbohydrates from the coal particles. Therefore, only the finest particles take part in the reaction. A second effect of adding coal dust as a fuel is the reduction of available oxygen and rendering the methane-air-coal dust mixture lean.

\section{Acknowledgement}

This work was supported by the Austrian Marshall Plan Foundation under the Scholarship 957121719222019.

Funding. Open access funding provided by Montanuniversität Leoben.

Open Access This article is licensed under a Creative Commons Attribution 4.0 International License, which permits use, sharing, adaptation, distribution and reproduction in any medium or format, as long as you give appropriate credit to the original author(s) and the source, provide a link to the Creative Commons licence, and indicate if changes were made. The images or other third party material in this article are included in the article's Creative Commons licence, unless indicated otherwise in a credit line to the material. If material is not included in the article's Creative Commons licence and your intended use is not permitted by statutory regulation or exceeds the permitted use, you will need to obtain permission directly from the copyright holder. To view a copy of this licence, visit http://creativecommons.org/licenses/by/4.0/.

\section{References}

1. Man, C. K.; Harris, M. L.; Weiss, E. S.: Determing flame travel measurements from experimental coal dust explosions, Proceedings of the Eighth International Symposium on Hazards, Prevention, and Mitigation of Industrial Explosions, Yokohama, Japan, 2010, NIOSH: 2010

2. Conti, R. L.; Cashdollar, K. L.; Thomas, R. A.: Improved 6.8-L furnace for measuring the autoignition temperatures of dust clouds, Washington D.C.: U.S. Dept. of the Interior, Bureau of Mines, 1993

3. Strebinger, C.: Modeling large-scale high speed methane gas deflagrations in confined spaces: Applications for longwall coal, Diss., Golden, Colorado School of Mines, Department of Mining Engineering, 2019

4. Fig, M. K. The impact of environmental conditions on methaneair explosion development and propagation through rock rubble in confinced space, Diss., Golden, Colorado School of Mines, Department of Mining Engineering, 2019

5. Du Plessis, J. J. L.: Active explosion barrier performance against methane and coal dust explosions, International Journal of Coa Science \& Technology, 2 (2015), p 216-268

6. Liu, Q.; Bai, C.; Li, X.; Jiang, L.; Dai, W.: Coal dust/air explosions in a large-scale tube, Fuel, 89/2 (2010), p 329-335

7. Ajrash, M. J.; Zanganeh, J.; Moghtaderi, B.: Impact of suspended coal dusts on methane deflagration properties in a large-scale straight duct, Journal of Hazardous Materials, 339 (2017), p 334-342

8. Ajrash, M. J.; Zanganeh, J.; Moghtaderi, B.: Methane-coal dust hybrid fuel explosion properties in a large scale cylindrical explosion chamber, Journal of Loss Prevention in the Process Industries, 40 (2017), p 317-328

Publisher's Note. Springer Nature remains neutral with regard to jurisdictional claims in published maps and institutional affiliations. 